\title{
JNPH
}

Volume 6 No. 2 (Oktober 2018)

(C) The Author(s) 2018

\section{GO GREEN LABORATORY SEBAGAI SOLUSI MENGURANGI PENYAKIT DEGENERATIF DI DESA SUKARAJA TAHUN 2018}

\section{GO GREEN LABORATORY AS A SOLUTION TO REDUCE DEGENERATIVE DISEASES IN SUKARAJA VILLAGE IN 2018}

\author{
GITA MAWAR SARI ${ }^{1}$, FIYA DINIARTI ${ }^{2}$, YOKA SINDARA ${ }^{3}$, WULANDARI $^{4}$ \\ PRASENTYA $^{5}$,YAN PASMAWI ${ }^{6}$ \\ MAHASISWA PROGRAM STUDI KESEHATAN MASYARAKAT, DOSEN PRODI \\ KESEHATAN MASYARAKAT, JL.MERAPI RAYA KEBUN TEBENG BENGKULU \\ E-mail : Sarigita70@yahoo.co.id
}

\begin{abstract}
ABSTRAK
Desa Padang Pelawi merupakan salah satu Desa di Kabupaten Seluma. Kabupaten Seluma memiliki luas wilayah sekitar 1.223,74 km² dengan jumlah penduduk sekitar 297.876 jiwa, masyarakat diwilayah ini rata-rata berasal dari suku serawai, rejang, jawa, sunda, dan lembak, rata-rata mata pencharian masyarakat adalah petani, PNS, karyawan dan pedagang serta pendidikan rata-rata tamat SD/SMP. Pekarangan rumah di Desa Padang Pelawi Kecamatan Sukaraja Kabupaten Seluma ini sebagian besar tidak dimanfaatakan oleh masyarakat, terlihat pada lahan pekarangan rumah cukup luas tetapi dibiarkan saja kosong dan tidak dimanfaatkan sedangkan tanaman herbal tumbuh liar di pinggir jalan, samping dan belakang rumah. Kondisi seperti ini dapat lebih parah ketika pekarangan tidak pernah dibersihkan, dibiarkan sehingga rumput liar tumbuh tinggi dan menjadi semak belukar. Berdasarkan survei awal diKecamatan Sukaraja didapatkan dari sepuluh orang, delapan orang terindikasi penyakit diabetes mellitus, asam urat dan hipertensi, wilayah ini terdapat potensi lokal yang belum disentuh dan dimanfaatkan seperti rata-rata pekarangan rumah luas, tumbuhan jenis herbal tumbuh secara liar dan tidak mendapatkan perawatan yang komphrehensif serta masyarakat didaerah ini belum menyadari pentingnya pemanfaatan pekarangan rumah menjadi go green laboratory. Target dan sasaran program ialan masyarakat Desa padang pelawi dengan tujuan untuk bekerjasama mengurangi resiko penyakit degenertif melalui pemanfaatan tanaman herbal. Metode pelaksanaan dari mulai sosialisasi, penyuluhan go green Laboratory, pelatihan olahan herbal (jenis mahkota dewa), pembuatan go green laboratory. Hal ini sebagai upaya pemenuhan kebutuhan tanaman obat herbal untuk mendukung dan mengembangkan potensi desa melalui tanaman herbal. Tujuan jangka panjangnya yaitu dengan adanya program PKM-M ini diharapkan dapat mengurangi resiko terhindar penyakit degenerative dan menciptakan Desa mandiri dalam mengolah tanaman obat herbal. Selain itu juga mampu mengimbangi obat kebutuhan yang ada di Desa Padang pelawi baik pada masyarakat maupun lingkungan, sehingga dapat menjadikan Desa sejahtera dan makmur oleh masyarakat mandiri.
\end{abstract}

Kata Kunci : Go Green Laboratory, Penyakit Degeneratif 


\begin{abstract}
Padang Pelawi Village is one of the villages in Seluma District. Seluma Regency has an area of about $1223.74 \mathrm{~km} 2$ with a population of about 297,876 people, the people in this region on average come from the Sarawak, Rejang, Javanese, Sundanese, and overtime tribes, the average people of the community are farmers, civil servants, employees and traders and average education graduate from elementary school / junior high school. This house yard in Padang Pelawi Village, Sukaraja Subdistrict, Seluma District, is mostly not used by the community, it is seen in the yard of the house that it is quite large but is left empty and not used while the herbs grow wild on the road, side and back of the house. Conditions like this can be worse when the yard is never cleaned, left so that weeds grow tall and become shrubs. Based on the initial survey in Sukaraja Subdistrict, there were ten people, eight people indicated diabetes mellitus, gout and hypertension, this area contained local potential that had not been touched and utilized such as the average home yard, herbs grown wild and not treated Comprehensive and community in this area have not realized the importance of using a home garden to go green laboratory. The target and target of the Padang Pelawi Village community program is to work together to reduce the risk of degenerative diseases through the use of herbal plants. The method of implementation from the start of socialization, counseling to go green Laboratory, training of herbal preparations (type of crown god), the making of go green laboratory. This is an effort to fulfill the needs of herbal medicinal plants to support and develop the potential of the village through herbal plants. The long-term goal of the PKM-M program is expected to reduce the risk of avoiding degenerative diseases and create an independent village in processing herbal medicinal plants. In addition, it is also able to compensate for the existing medicine needs in Padang Pelawi Village both for the community and the environment, so that it can make the village prosperous and prosperous by the independent community.
\end{abstract}

\title{
Keywords: Go Green Laboratory, Degenerative Disease
}

\section{PENDAHULUAN}

Penyakit degeneratif menjadi penyebab utama kematian secara global.Data WHO menunjukkan bahwa dari 57 juta kematian yang terjadi di dunia pada tahun 2008, sebanyak 36 juta atau hampir dua pertiganya disebabkan oleh penyakit degeneratif. Penyakit degenerative membunuh penduduk dengan usia yang lebih muda. Menurut Badan Kesehatan Dunia WHO, kematian akibat penyakit tidak menular (PTM) diperkirakan akan terus meningkat di seluruh dunia, peningkatan terbesar akan terjadi di negara-negara menengah dan miskin, lebih dari dua pertiga (705\%) dari populasi global akan meningal akibat penyakit degeneratif seperti kanker, jantung, stroke dan diabetes. (Kemenkes, 2012)

Data dari Riskesdas Tahun 2007 menyatakan bahwa selama tahun 1995-2007 di Indonesia proporsi penyakit menular telah menurun sepertiganya dari $44,2 \%$ menjadi $28,1 \%$ akan tetapi proporsi penyakit tidak menular mengalami peningkatan cukup tinggi dari $41,7 \%$ menjadi $59,5 \%$ sedangkan gangguan maternal/perinatal dan kasus cedera relatif stabil. Menurut Profil penyakit degeneratife tahun 2011, di Indonesia tahun 2008 terdapat 582.300 laki-laki dan 481.700 perempuan meninggal karena penyakit degenerative. (Kemenkes, 2012)

Penyakit Hipertensi di Kota Bengkulu pada tahun 2015 penduduk yang yang didiagnosa hipertensi berkisar 3.647 orang atau 31,36\%. Dibanding tahun 2014 terjadi peningkatan jumlah penduduk yang terdeteksi menderita hypertensi sebesar 3,12\% karena tahun 2014 penduduk penderita hypertensi hanya 28,24\%. (Profil Kesehatan Kota Bengkulu, 2015). 
Penyakit degeneratif di Provinsi Bengkulu merupakan masalah kesehatan yang serius dikarenakan sebagian besar masyarakat Bengkulu berasal dari suku serawai. Masyarakat Suku Serawai menyukai makanan bersantan, pedas dan asin. Masyarakat diwilayah ini merupakan urban community dikarenakan perilaku life styles yang tidak baik seperti merokok, konsumsi makanan junk food, soft drink, makanan kaleng, serta kurang berolahraga dikarenakan waktu kerja yang padat, determinan ini dapat meningkatkan beresiko penyakit degeneratif.

Pemberdayaan masyarakat urban melalui go green laboratory sebagai solusi mengurangi resiko penyakit degenerative melalui pemanfaatkan pekarangan rumah didaerah dengan melihat potensi lokal yang besar seperti lahan yang luas, iklim yang mendukung, tanaman herbal yang tumbuh tetapi belum dimanfaatkan dengan baik oleh masyarakat padahal dengan menanam dan merawat tanaman herbal dapat menghasilkan manfaat yang sangat besar bagi masyarakat, selain untuk dikonsumsikan, juga dapat dijadikan ramuan tradisional bahkan dapat menambah penghasilan masyarakat dari hasil penjualan tanaman herbal tersebut.

Provinsi Bengkulu konsep Go Green Laboaratory belum dilakukan secara sistematis, masyarakat hanya mengetahui jenis tanamannya saja tetapi tidak mengetahui manfaat dan mengolah tanaman herbal tersebut menjadi ramuan yang berkhasiat untuk kesehatan masyarakat. Dengan mengaplikasikan konsep Go Green laboratory adalah sebagai wadah edukasi dalam pemberdayaan masyarakat dari mulai menanam, merawat, mengolah, dan memasarkan produk yang dihasilkan.

Provinsi Bengkulu kaya akan sumber bahan obat alam dan obat tradisional yang telah digunakan oleh sebagaian besar masyarakat secara turun-menurun. Diperoleh dengan mudah bahan bakunya dapat ditanam diperkarangan sendiri, murah, dan dapat diramu sendiri dirumah.Hampir setiap orang pernah menggunakan tumbuhan obat untuk mengobati penyakit atau kelainan yang timbul pada tubuh selama hidupnya, baik ketika masih bayi, kanak-kanak maupun setelah dewasa.Dan diakui serta dirasakan manfaat tumbuhan obat ini dalam penyembuhan penyakit yang diderita.untuk menyembuhkan suatu penyakit tidak hanya dapat disembuhkan dengan pengobatan modern, tetapi juga disembuhkan dengan menggunakan dari tanaman obat-obat herbal (alami).

Berdasarkan survei awal diKecamatan Sukaraja didapatkan dari sepuluh orang, delapan orang terindikasi penyakit diabetes mellitus, asam urat dan hipertensi, wilayah ini terdapat potensi lokal yang belum disentuh dan dimanfaatkan seperti rata-rata pekarangan rumah luas, tumbuhan jenis herbal tumbuh secara liar dan tidak mendapatkan perawatan yang komphrehensif serta masyarakat didaerah ini belum menyadari pentingnya pemanfaatan pekarangan rumah menjadi Go Green laboratory.

Terinspirasi dari masalah penyakit degeneratif yang semakin merajalela di Bengkulu saat ini, kami berfikir seharusnya masyarakat ddiberdayakan untuk memanfaatkan potensi lokal dan memberdayakan masyarakat.Pemerintah Provinsi Bengkulu seharusnya sadar bahwa masalah kesehatan terutama penyakit degeneratif ini tidak dapat ditanggulangi dengan baik jika masyarakat tidak diedukasi dengan baik pula. Melalui program Go Green laboratoryakan bersinergi dengan program pemerintah pusat dalam bentuk Gerakan Masyarakat (GERMAS) yang mengarah kepada upaya promotif dan preventif. Oleh karena itu diharapkan Program Kerativitas Mahasiswa (PKM) ini dapat membantu masyarakat untuk menyadari bahwa pekarangan rumah dapat dimanfaaatkan menjadi wadah untuk menanam tanaman herbal, dan mengolah tanaman tersebut dengan metode yang sederhana, murah dan praktis serta benilai. Go Green Laboratory juga dapat membatu pemerintah Provinsi Bengkulu dalam menanggulangi permasalahan kesehatan, ekonomi dan sosial. Berdasarkan latar belakang masalah yang 
telah dijelaskan, maka dalam program ini rumusan masalah ditekankan bagaimana pemanfaatan tanaman herbal yang tumbuh liar di sekitar rumah, pemanfaatan pekarangan rumah yang luas untuk dijadikan go green laboratory, pemanfaatan tanaman herbal menjadi ramuan tradisional yang berkhasiat dan menyehatkan.

Tujuan kegiatan kegiatan ini meningkatkan pengetahuan dengan cara mengedukasi masyarakat penyuluhan kepada masyarakat tentang konsep go green laboratory, deningkatkan ketrampilan masyarakat dalam membuat ramuan herbal, dan meningkatkan partisipasi masyarakat untuk membentuk go green laboratory dengan memanfaatkan lahan pekarangan rumah, tanaman herbal yang tumbuh disekitar rumah dan pemanfaatan barang bekas untuk dijadikan media tanam (POT).

\section{METODE PENELITIAN}

Kegiatan PKM-M dengan judul go green laboratorydilaksanakan di Desa Padang pelawi Kecamatan Sukaraja Kabupaten Seluma dari mulai bulan maret sampai dengan mei 2018. Metode yang digunakan dalam pelaksanaan kegiatan merupakan sebuah tahapan yang disusun secara sistematis, berikut ini gambaran flow map yang akan berjalan dari mulai tahap persiapan ( survei awal, izin lokasi, sosialisasi kegiatan PKM-M), tahap pelaksanaan (penyuluhan, pembentukan go green laboratory, pelatihan olahan herbal), tahap monitoring dan evaluasi kegiatan, instrument yang digunakan dalam kegiatan ini berupa kuesioner dan lembar pre/post test.Hasil dari kegiatan ini dapat dikembangkan melalui upaya keberlanjutan tanaman herbal dengan cara penjualan bibit tanaman herbal, olahan tanaman herbal berupa minuman berkhasiat ataupun proses pengeringan alu dilakukan pemasaran serta Desa Padang Pelawi dapat dijadikan daerah wisata herbal.

\section{HASIL PENELITIAN}

Melalui PKM- Pengabdian Masyarakat dengan judul pemberdayaan Urban Community Melalui Go Green Laboratory sebagai solusi mengurangi resiko penyakit degenerative di Desa Padang Pelawi Kecamatan Sukaraja Kabupaten Seluma dapat dinilai sudah berjalan dengan baik, terlihat pada semua kegiatan yang dilakukan sesuai dengan timeline yang sudah terjadwal.

Langkah-langkah kegiatan program ini adalah :

\section{a) Persiapan}

Langkah pertama pada program ini adalah survei dan orientasi wilayah dengan tujuan untuk mengetahui permasalahan dan potensi yang ada di Desa Padang pelawi, setelah potensi tersebut dapat dimanfaatkan, Kegiatan selanjutnya pengurusan perizinan lokasi PKM-Pengabdian masyarakat dengan tujuan untuk mendapatkan dukungan, koordinasi pada berbagai pihak terutama kepada Kepala Desa dan ketua RT dan ketua mitra kerja (IKI PTPN VII Padang Pelawi). Respon dari pihak-pihak tersebut sangat baik dan mendukung program, yang diharapkan pula dapat berkembang dan diikuti oleh semua masyarakat di Desa Padang Pelawi.

Sosialisasi awal dilakukan pada hari rabu, 25 April 2018 yang diikuti oleh warga Desa Padang Pelawi, respon warga pada pengenalan awal ini sangat baik, mereka mendukung sepenuhnya program ini, hal tersebut diketahui dari kuesioner yang diberikan kepada warga dan jumlah peserta yang hadir berkisar 50 orang berasal dari karang taruna remaja, kelompok lansia dan kelompok IKI PTPN VII Padang Pelawi. Kegiatan selanjutnya adalah dengan terjun langsung ke masyarakat sebagai sarana pendekatan pada masyarakat, pengenalan program lebih jauh dan sosialisasi tentang adanya program di setiap rumah baik melalui kegiatan IKI PTPN VII ataupun dalam kegiatan lainnya. 
b) Pelaksanaan

Dalam pelaksanakan kegiatan PKM-

M, kegiatan penyuluhan tentang pemberdayaan Urban Community Melalui Go Green Laboratory sebagai solusi mengurangi resiko penyakit degenerative di Desa Padang Pelawi Kecamatan Sukaraja Kabupaten Seluma bertujuan untuk meningkatkan kesadaran masyarakat untuk memanfaatkan pekarangan yang kosong menjadi wadah tanaman herbal yang berkhasiat untuk kesehatan, pemanfaatan barang bekas untuk dijadikan media tanam/POT sebagai solusi untuk mengurangi tempat perkembangbiakan nyamuk sehingga masyarakat dapat terhindar dari penyakit demam berdarah dengue (DBD), pemanfaatan tanaman herbal yang tumbuh di sekitar rumah. Tekhnik pengukuran tingkat pengetahuan menggunakan pre/post test, dengan didapatkan hasil Analisa data rata- rata pengetahuan sebelum diberikan penyuluhan berkisar $6,08 \%$ dan setelah diberikan penyuluhan rata-rata pengetahuan baik dengan 7,04\%.

Kegiatan selanjutnya berupa pembentukango green laboratory sebagai pilot project percontohan dengan tujuan untuk melindungi, melestarikan kekayaan alam melalui tanaman yang ada disekitar kita, serta meningkatkan kesehatan masyarakat guna mengurangi resiko penyakit degeneratif. Dalam pembentukan go green laboratory, tim PKM-M, IKI PTPN VII dan masyarakat menemukan tanaman herbal disekitar rumah sebanyak 50 jenis tanaman, diantaranya yaitu, yang mana manfaatnya untuk mengurangi penyakit diabetes mellitus, hipertensi, ginjal, gastritis, Asam urat, kolestrol dan lain-lain.

Tanaman herbal yang terdapat pada go green laboratory diantaranya yaitu kunyit putih, jahe merah, jahe putih, daun tarpo, insulin, empedu, sarbiloto, panda warsi, pudding, kencur, kunti, kunyit, brotowoli, sirih merah, daun salam, mahkota dewa, gingseng, kumis kucing, binahong, merirah, krohot, keladi, jeruk, antingan, laos, benglai, temu ireng, menghudu, daun seris, pecah beling, patah tulang, papaya tangerang, katuk, jarak, stokot dewe, blunglai, dewe, sirsak, kemangi, ketepeng, temulawak, pandan, luntas, gingseng, cocor bebek, pegagan, temulawak, pandan, luntas, gingseng, cocor bebek, pegagan, daun keladi, talas, ciplukan, bayam duri, lidah buaya, akar wangi, lempuyang, dan bakung.

Kegiatan selanjutnya berupa pelatihan pembuatan olahan herbal yang berasal dari jenis tanaman mahkota dewa menjadi minuman berkhasiat untuk mengurangi penyakit diabetes mellitus. Proses pembuatannya dari mulai spemisahan kulit dan buah, pencacahan kulit, pengeringan, perebusan dan layak konsumsi. Adapun hasil yang telah dicapai adalah dalam pembuatan olahan herbal (mahkota dewa) telah dijadikan minuman herbal. Minuman herbal ini dapat diokonsumsi oleh penderita diabetes mellitus agara dapat mengurangi kadar gulan dalam darah.

\section{PEMBAHASAN}

Dari kedelapan indikator ketercapaian target luaran PKM-M sudah mencapai keberhasilan rata-rata sebesar $95 \%$. Dilihat dari indikator tersebut yang masih kurang adalah penyusunan laporan kemajuan kegiatan, dokumentasi, laporan keuangan, dan penyusunan artikel ilmiah $80 \%$. Sesuai dengan tujuan PKM-M manfaat program ini di Desa Padang pelawi sekitar 100\%, hal ini akan terus bertambah karena masih melakukan pelatihan dan pemantauan sebagai program PKM-Risetkdikti selesai, dan kalapun program ini selesai kami mempunyai harapan agar PKM-M terus berjalan. Penyusunan laporan akhir kegiatan masih banyak yang kurang, dan diusahakan akan selesai.

\section{KESIMPULAN}

1. Meningkatkan pengetahuan dengan cara mengedukasi masyarakat penyuluhan kepada masyarakat tentang konsep go green laboratory terlihat daridengan didapatkan hasil Analisa data rata- rata pengetahuan sebelum diberikan 
penyuluhan berkisar $6,08 \%$ dan setelah diberikan penyuluhan rata-rata pengetahuan baik dengan 7,04\%.

2. Meningkatknya ketrampilan masyarakat dalam membuat olahan herbal dari tanaman mahkota dewa(berbentuk minuman teh mahota dewa untuk mengurangi penyakit dibetes mellitus).

\section{SARAN}

Meningkatkan ketrampilan masyarakat dengan wujud nyata pembentukan go green laboratory dengan memanfaatkan lahan pekarangan rumah, tanaman herbal yang tumbuh disekitar rumah dan pemanfaatan barang bekas untuk dijadikan media tanam (POT).Tanaman herbal yang ditanam sebanyak 50 jenis tanaman, diantaranyakunyit putih, jahe merah, jahe putih, daun tarpo, insulin, empedu, sarbiloto, panda warsi, pudding, kencur, kunti, kunyit, brotowoli, sirih merah, daun salam, mahkota dewa, gingseng, kumis kucing, binahong, merirah, krokot, keladi, jeruk, antingan, laos, benglai, temu ireng, mengkudu, daun seris, pecah beling, patah tulang, papaya tangerang, katuk, jarak, stokot dewe, blunglai, dewe, sirsak,kemangi, ketepeng, temulawak, pandan, luntas, gingseng, cocor bebek, pegagan, daun keladi, talas, ciplukan, bayam duri, lidah buaya, akar wangi, lempuyang, dan bakung.

\section{DAFTAR PUSTAKA}

Dinas Kesehatan. 2015. Profil Kesehatan Kota Bengkulu : Dinas Kesehatan Kota Bengkulu

Kementrian Kesehatan RI. 2012. Riset Kesehatan Dasar : Kementrian Kesehatan RI 